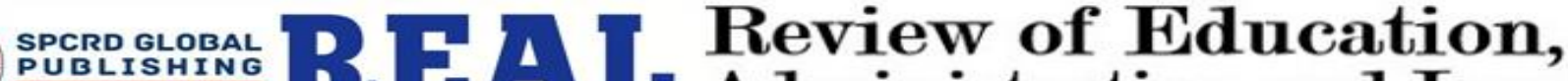 Sustainable solutions 1 Administration and LaW \\ Journal homepage: http://real.spcrd.org ISSN (Print): 2708-1788

\section{Examining the Impact of Summer Vacations on ESL Learners' Retention in Reading Comprehension}

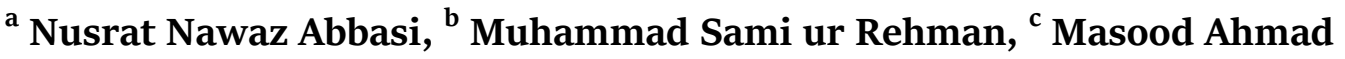 \\ a Assistant Professor Department of Education, The Govt. Sadiq College Women University, Bahawalpur, Pakistan \\ Email: nusrat.nawaz@gscwu.edu.pk \\ ${ }^{\mathrm{b}}$ Subject Specialist, Govt. Abbasia Higher Secondary School Bahawalpur, Pakistan \\ Email:samibwp10@gmail.com \\ ${ }^{c}$ Assistant Professor, Department of Educational Training, The Islamia University of Bahawalpur, Pakistan \\ Email: masood.ahmad@iub.edu.pk
}

\begin{tabular}{l}
\hline ARTICLE DETAILS \\
\hline History: \\
Accepted o3 March 2021 \\
Available Online March 2021 \\
\hline Keywords: \\
Summer Vacations, ESL \\
Learners' Retention, Reading \\
Comprehension \\
JEL Classification: \\
D83, P36
\end{tabular}

DOI: $10.47067 /$ real.v4i1.111

\section{ABSTRACT}

Vacations affect students' level of retention and their academic performance since students unwillingly bother to actively remain in touch with academic activities during vacations. This study aims to examine the impact of summer vacations on ESL learners' retention in reading comprehension. Specifically, it investigated whether summer vacations affect ESL learners' retention level in reading comprehension. A sample of 240 ESL learners of secondary schools from Southern Punjab, Pakistan was selected through convenient sampling method. Both males and females were addressed in the study. A comprehension test was designed in line with the revised Barrett's taxonomy of reading comprehension based on the contents of the English textbook taught to secondary school grade $X$ students. SPSS version 22 was employed to analyze the quantitative data. The analysis indicates that there was an impact of summer vacations on learners' retention in reading comprehension. It also reveals that the learners acquired better scores in pre-test that was conducted before starting summer vacations as compared to the scores of post-test, which was given after summer vacations. A two-sample t-test reveals a significance difference between the performance of urban and rural learners and the learners studying in public and private schools as well. A significant gender difference was also found between the scores of pre-test and post-test. Based on the findings of the study, some implications and recommendations were furnished for ESL learners to improve their academic performance in reading comprehension by utilizing summer vacations effectively.

(C) 2021 The authors. Published by SPCRD Global Publishing. This is an open access article under the Creative Commons AttributionNonCommercial 4.0

Corresponding author's email address: nusrat.nawaz@gscwu.edu.pk

\section{Introduction}

Generally reading comprehension is considered as a complex phenomenon of decoding symbols, 
and grasps the meanings of the text. It is known as the source of language acquisition, communication with others, to share the information and novel ideas. This is a complex interaction between the textual material and reader. So, reader shape the knowledge of the text according to the prior knowledge, life experiences, attitude, culturally and socially situated language community (Pikulski \& Chard, 2005).

Peregoy and Boyle (2005) elaborated that reading based on set of skills that helps the reader to make sense and derived the contextual meaning from the written piece of work. According to Oakhil, Kate and Carsten (2015), reading comprehension plays an important role not only to understand text, it also helps the reader for broader perspective to get good grades in education and better employment. Moreover, reading involves various cognitive skills including recognition of letters and words, syntax knowledge, recognition of structure and types of text (Richards \& Schmidt, 2010). In this particular study, reading comprehension is a complex cognitive process that involves three major reading skills in line with Barrett's (1968) taxonomy of reading comprehension are literal comprehension, reorganization comprehension and inferential comprehension. The study addresses to examine the impact of summer vacations on secondary school ESL learners' retention in the aforementioned reading comprehension skills. According to this study, reading ability of readers refers to five sub-skills such as to locate supporting detail, find main idea, find sequence, make comparison, identify cause and effect relationship under literal comprehension, four sub-skills, namely; classify, outline, summarize and synthesize in reorganization comprehension and two sub-skills e.g. make inference and draw conclusion under inferential comprehension.

It is one of the most important skills for the majority of the learners, in order to ensure success in learning. In addition, reading comprehension heavily relies on vocabulary and background knowledge of learner. However, the learners normally lack of vocabulary and understanding of the second language structure to comprehend the text properly. Moreover, Anderson (2003) explored that learners are not aware of most familiar word and expression of those word and which show the deficiencies in mastery of reading talents such as precise, reorganization and inferential understanding is considered as a hindrance in comprehension of the text. Therefore, continuous efforts without prolonged intervals besides the background knowledge of the text help learners to comprehend the textual materials, which extend their literacy skills in English and enhance their performance in reading comprehension skills (Block \& Parris, 2008).

Cleland (1965) developed a model, which proposed six levels of reading comprehension, namely; perception, appreciation, abstraction, appraisal, ideation and application. These levels assist ESL instructors and learners employ their intellectual faculties to comprehend the language of a writer or speaker. The first level, perception is considered as a significant response rather than simple recognition as compared to the appreciation where the procedure of linking new resources is referred to one's training of skills. These two basic levels of Cleland's model relate directly to the levels referred to by other authors as literal comprehension and inferential understanding.

Reading comprehension of a written text is a complex process which not only based on what is writers' point of view and coded in the written material, but it also involves the other factors as well, that is background knowledge of the reader, decoding ability of the reader, experiences, feeling purposes and specially type of written material (descriptive, narrative or expository etc.) and more specifically use of reading strategy by the reader (Samuels, 2012). Thus, the reader remains active to make reading process meaningful and effective. Moreover, Yaping (2002) elaborated that it is resulted by the inetraction between reader, backgroud knowledge of the reader and written material. 
Various factors affect ESL learners' performance in reading comprehensions. García (1991) states that learners' background knowledge, types of reading comprehension questions, explicitness of the information presented in the texts, learners' general and test-specific vocabulary knowledge, familiarity with vocabulary terms, tendency to interpret the texts literally and elicit more information are some common factors that affect learners' performance in reading comprehension. Snow (2002) reported some factors, namely; vocabulary knowledge, classroom instruction, cognitive, educational, linguistic, discourse analytic, sociolinguistic and cultural perspectives, which affect learners' proficiency in reading comprehension. Moreover, some motivational factors, such as interest in the topic and selfconcept might change direction and pace of learning in reading comprehension.

The results of the previous studies carried out by Kieffer and Lesaux (2008). Basit, Hughes, Iqbal, and Cooper (2015) reveal that learners' abilities, inter and intra individual differences, reader's motivation, goals, and purposes, type of text (narrative, descriptive and expository, etc.), thinking, speaking, writing and reading is also helpful factors to improve learners' reading performance (Gee, 1990).

A study conducted by Graves, Juel, and Graves, (1998) concluded that word recognition, application of world knowledge and reasoning abilities are significant factors to affect learners' reading abilities. Previous studies carried out by Stanovitch (1991),Vellutino and Scanlon (2001), and Vellutino, Scanlon, and Lyon (2000) reported some factors such as a) vocabulary and linguistic knowledge, b) engagement and motivation, c) discourse knowledge d) cognitive and metacognitive strategy development, e) non-linguistic capabilities and procedures, f) an considerate of the purposes and goals of reading,) field information, attention, inferring, visualization, reasoning, working memory and critical analysis. It can be viewed that various factors affect learners' reading performance. Learners' continuous and steady efforts also put positive impact on their reading performance. Therefore, those learners who continuously struggle hard without any break succeed. The academic calendar of any institution indicates that what to extent the learners enjoy many holiday throughout the year. The number of vacations varies from country to country and territory to territory based on the weather condition of that locality. The learners, generally, remain untouched with academic activities Pagan and Sénéchal (2014). Therefore, vacations, particularly summer vacations affect learners' academic performance.

In connection with summer vacations in Pakistan, teachers and learners of the province of the Baluchistan, Punjab, Sindh and Khyber Pakhtunkhwa enjoy summer vacation for 10 to 12 weeks starting from the first week of June until the third week of August every year. The reason behind the long span of summer vacations is the severe weather conditions with high temperature ranged between 45 and 52 centigrade during this period (Pakistan Meteorological Department, 2015). Contrarily, the teachers and learners hailing from northern areas of Pakistan such as Azad Kashmir, Gilgit-Baltistan and some areas of Baluchistan enjoy winter vacations for only two weeks instead of summer vacations since heavy snow paralyzes life in these areas. Therefore, the teachers assign extra home tasks for these days, so that the learners may continue their academic activities during vacations.

In view of the Pakistani contexts, the learners try their best to accomplish their home tasks during summer vacations. However, many of the learners could not even complete their home tasks due to various reasons. This factor affects their academic performance. It also puts negative impacts on their reading proficiencies (Siddique, 2011). Thus, the current study aims to analyze the impact of summer vacations on ESL learners' retention in reading comprehension. 
The major objective of the present research was to examine the impact of summer vacations on ESL learners' retention in reading comprehension. Comparisons between the impact of summer vacations on retention level among the learners of urban and rural schools, public and private schools, males and females in reading comprehension were also made in the study. In order to achieve the objectives of the study, following research questions are designed.

The present research focused on the following research questions.

1: What is the impact of summer vacations on ESL learners' retention in reading comprehension?

2: What is difference between the impact of summer vacations among urban and rural school learners' retention in reading comprehension?

3: What is difference between the impact of summer vacations among private and public school learners' retention in reading comprehension?

4: What is difference between the impact of summer vacations among male and female learners' retention in reading comprehension?

Following hypotheses were made to make comparison between the learners of urban and rural schools, public and private schools and males and females to examine the impact of retention in reading comprehension. The hypotheses were as follows:

1- $\mathrm{H}_{0}$. There is no significant difference between the impact of summer vacations on retention level in reading comprehension among the learners of urban and rural schools.

2- $\mathrm{H}_{1}$. There is a significant difference between the impact of summer vacations on retention level in reading comprehension among the learners of urban and rural schools.

3- $\mathrm{H}_{0}$. There is no significant difference between the impact of summer vacations on retention level in reading comprehension among the learners of private and public schools.

4- $\mathrm{H}_{1}$. There is a significant difference between the impact of summer vacations on retention level in reading comprehension among the learners of private and public schools.

5- $\mathrm{H}_{\mathrm{o}}$. There is no significant difference between the impact of summer vacations on retention level in reading comprehension among males and females.

6- $\mathrm{H}_{1}$. There is a significant difference between the impact of summer vacations on retention level in reading comprehension among males and females.

\section{Population and Sampling}

The target population was the ESL learners of class 10 from secondary schools. Ten secondary were selected through convenient sampling method. Two hundred and forty (24 from every school) students were randomly selected from 10 schools situated in District Vehari, Pakistan. Out of 10 schools, 5 schools ( 2 from urban area and 3 from rural area) were taken from the public sector, while 5 schools ( 3 from urban area and 2 from rural area) were chosen from the private sector.

\section{Research Instrument}

A reading comprehension test consisting of 55 multiple choice questions was developed carefully by the researcher. Three major reading skills, namely; literal comprehension, reorganization comprehension and inferential comprehension in line with Barrett's (1968) taxonomy of reading comprehension and the English language objectives for grade 10 specified by the Ministry of Education Pakistan (2006) were focused in the reading comprehension test. Eleven passages were selected from the 1oth class English Textbook of the Punjab Textbook Board (PTB) Lahore, Pakistan to address all reading skills followed by five comprehension questions under each text. Four distractors were given 
for each question.

Five sub-skills under literal comprehension, namely; locating supporting detail, finding main ideas, finding sequence, making comparison and identifying cause and effect relationship were focused. Four sub-skills such as classifying, outlining, summarizing and synthesizing were addressed in reorganization comprehension. Two sub-skills such as making inference and drawing conclusion were considered under inferential reading comprehension in the reading comprehension test. Literal comprehension, reorganization comprehension and inferential comprehension consisted of 25 items (item 1-25), 20 items (item 26-45) and 10 items (item 46-55) respectively.

With reference to the validity of the instrument, two experienced content experts tested the validity. One expert was a university lecturer while the other was a secondary school ESL teacher who checked the difficulty level, length of the texts, the comprehension questions along with distractors. Appropriate changes were made in the reading comprehension test in the light of the constructive comments and feedback of content experts. After testing the validity of the instrument, a small scale pilot study in the District of Vehari Pakistan was conducted to determine the reliability of the research tool. Ninety (90) learners contributed in the pilot study. The test scores of the learners in literal comprehension, reorganization comprehension and inferential comprehension were 0.852 , 0.891 and 0.952 respectively, which indicate high reliability (Airasian, Gay, \& Mills, 2000; Bonito, Ruppel, \& Keyton, 2012).

\section{Data Collection and Analysis}

The qualitative data were collected by using the reading comprehension test developed by the researcher for grade 1olearners from District Vehari, Pakistan. Before gathering the data, the principals of the respective secondary schools were requested that was granted accordingly. The reading comprehension test developed by the researcher was used as pre-test and the participants were given 75 minutes to complete it. The same test was also used as post-test and same time duration was given to the respondents to complete it. The pre-test was administered during the last week of May while the post-test was conducted after three months in the first week of September.

\section{Results}

All the major reading skills along with sub-skills included in the reading comprehension test were analyzed separately. The results of the study were also made based on geographical locations, public and private sector and gender to examine the impact of summer vacations on ESL learners' retention in reading comprehension. The results of the study are presented in different tables and figures as follows. The results of the participants are presented in Table 1 followed by an explanation in pursuance of RQ 1: What is the impact of summer vacations on ESL learners' retention in reading comprehension? 
Table 1 Learners' Mean Scores in reading comprehension $(\mathrm{N}=\mathbf{2 4 0})$

\begin{tabular}{|c|c|c|c|c|c|c|}
\hline $\begin{array}{l}\text { Major reading } \\
\text { skill }\end{array}$ & Sub-skill & $\begin{array}{l}\text { score in each } \\
\text { sub-skill }\end{array}$ & $\begin{array}{l}\text { Pre-test } \\
\text { Score }\end{array}$ & $\begin{array}{l}\text { Post-test } \\
\text { Score }\end{array}$ & Finding & T-value \\
\hline \multirow{5}{*}{$\begin{array}{l}\text { Literal } \\
\text { Comprehension }\end{array}$} & $\begin{array}{l}\text { Locate supporting } \\
\text { detail }\end{array}$ & 5 & 5 & 4 & Loss & \multirow{12}{*}{0.00} \\
\hline & Find main idea & 5 & 4 & 3 & Loss & \\
\hline & Find sequence & 5 & 4 & 4 & No effect & \\
\hline & Make comparison & 5 & 3 & 3 & No effect & \\
\hline & $\begin{array}{l}\text { Identify cause and } \\
\text { effect relationship }\end{array}$ & 5 & 3 & 2 & Loss & \\
\hline \multirow{4}{*}{$\begin{array}{l}\text { Reorganization } \\
\text { Comprehension }\end{array}$} & Classify & 5 & 5 & 4 & Loss & \\
\hline & Outline & 5 & 4 & 3 & Loss & \\
\hline & Summarize & 5 & 3 & 3 & No effect & \\
\hline & Synthesize & 5 & 3 & 2 & Loss & \\
\hline \multirow{2}{*}{$\begin{array}{l}\text { Inferential } \\
\text { Comprehension }\end{array}$} & Make inference & 5 & 4 & 3 & Loss & \\
\hline & Draw conclusion & 5 & 3 & 2 & Loss & \\
\hline \multicolumn{2}{|l|}{ Total } & 55 & 41 & 33 & Loss & \\
\hline
\end{tabular}

$P<0.05$

Table 1 indicates that the learners' obtained scores in pre-test are 41 while in post-test they got 33 scores out of 55 in the reading comprehension test. It also indicates that they obtained maximum scores ( 5 out of 5 ) in two sub-skills, namely; locating supporting detailand classifying in pre-test. On the other hand, the participants did not get 5 marks out 5 in any sub-skill in post-test. Thus, the learners' performance in reading comprehension declined after summer vacations. The calculated t-value (o.oo) also indicates that there is a significant difference between the obtained scores of the learners in pretest and post-test. In order to give a clear picture to the readers, the learners' scores are shown in a bar graph in Figure 1. Figure 2 is drawn to indicate the gradual declines in the obtained in post-test.

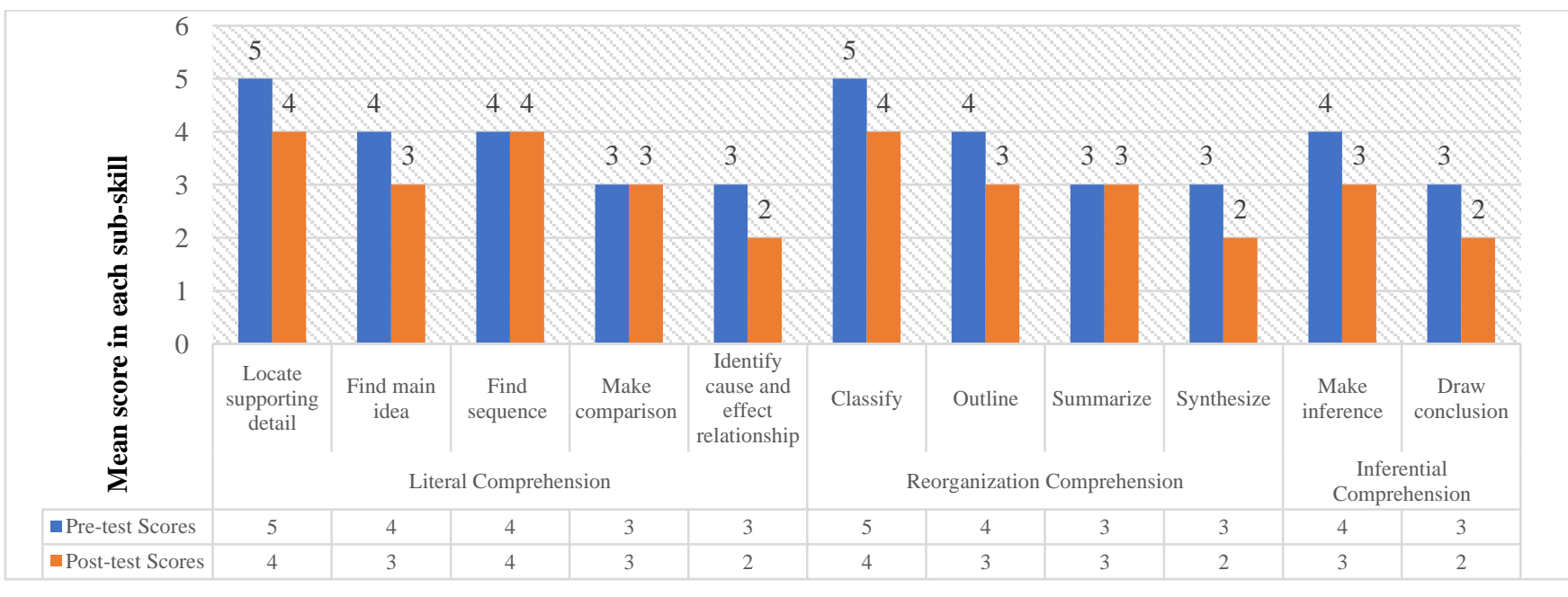

Figure 1 Learners' scores in pre-test and post-test 


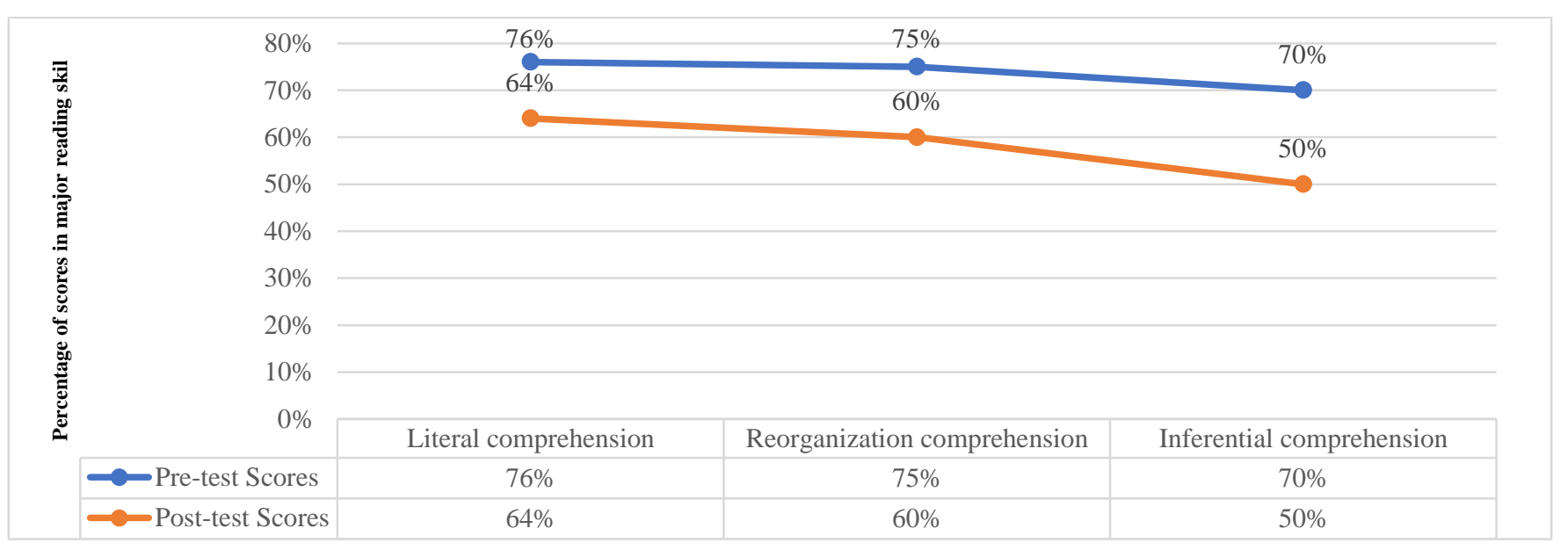

Figure 2 Comparison of learners' scores in pre-test and post-test

Figure 2 presents the comparison of learners' obtained scores in pre-test and post-test as well. It also indicates a gradual decline in scores in post-test. Figure 2 reveals that learners' scores in literal comprehension, reorganization and inferential comprehension were $76 \%, 75 \%$ and $70 \%$ respectively in pre-test. On the other hand, the learners' gained scores in literal comprehension, reorganization comprehension and inferential comprehension were $64 \%, 60 \%$ and $50 \%$ respectively in post-test. It shows a gradual decrease in the participants' performance in reading comprehension after summer vacation. It can be concluded that summer vacations put a negative impact on students' performance in reading comprehension.

The obtained scores of urban and rural in reading comprehension are analyzed in pursuance of RQ 2: What is difference between the impact of summer vacations among urban and rural school learners' retention in reading comprehension?

Table 2 presents the scores of urban and rural schools in pre-test and post-test. The data presented in Table 2 indicate the performance of the learners of urban and rural schools. It shows that both urban and rural learners got maximum marks (5 out of 5 ) in making the comparison in literal comprehension in pre-test. It also indicates that both urban and rural learners got a minimum score (1 out of 5) in summarizing in reorganization comprehension in pre-test while rural learners obtained a minimum score ( 1 out of 5 ) in making inference and drawing conclusions in inferential comprehension in post-test. Thus, it can be concluded that the learners diminished their performance in reading comprehension through summer vacations. The calculated t-values (0.03 and 0.02) indicate that there is a significant difference between the mean scores of urban and rural learners in pre-test and post-test as well. Following hypotheses were made to examine the impact of summer vacations on retention level in reading comprehension among the learners of urban and rural schools. 
Table 2 Urban and Rural Learners' Mean Scores in reading comprehension

\begin{tabular}{|c|c|c|c|c|c|c|c|c|c|c|}
\hline \multirow[b]{2}{*}{$\begin{array}{l}\text { Major } \\
\text { reading skill }\end{array}$} & \multirow[b]{2}{*}{ Sub-skill } & \multirow{2}{*}{$\begin{array}{l}\text { Score in } \\
\text { each } \\
\text { skill }\end{array}$} & \multicolumn{4}{|c|}{ Urban learners $(n=120)$} & \multicolumn{4}{|c|}{ Rural learners $(\mathrm{n}=120)$} \\
\hline & & & $\begin{array}{l}\text { Pre-test } \\
\text { Score }\end{array}$ & $\begin{array}{l}\text { Post- } \\
\text { test } \\
\text { Score }\end{array}$ & Finding & $+\stackrel{0}{\frac{0}{\pi}}$ & $\begin{array}{l}\text { Pre- } \\
\text { test } \\
\text { Score }\end{array}$ & $\begin{array}{l}\text { Post- } \\
\text { test } \\
\text { Score }\end{array}$ & Finding & $+\stackrel{\frac{0}{7}}{\stackrel{7}{>}}$ \\
\hline \multirow{5}{*}{$\begin{array}{l}\text { Literal } \\
\text { Comprehens } \\
\text { ion }\end{array}$} & $\begin{array}{l}\text { Locate } \\
\text { supporting } \\
\text { detail }\end{array}$ & 5 & 4 & 3 & Loss & \multirow{11}{*}{0.03} & 3 & 2 & Loss & \multirow{11}{*}{0.02} \\
\hline & $\begin{array}{ll}\text { Find main } \\
\text { idea }\end{array}$ & 5 & 3 & 2 & Loss & & 2 & 2 & $\begin{array}{l}\text { No } \\
\text { effect }\end{array}$ & \\
\hline & Find sequence & 5 & 3 & 2 & Loss & & 2 & 2 & $\begin{array}{l}\text { No } \\
\text { effect }\end{array}$ & \\
\hline & $\begin{array}{l}\text { Make } \\
\text { comparison }\end{array}$ & 5 & 5 & 3 & Loss & & 5 & 3 & Loss & \\
\hline & $\begin{array}{l}\text { Identify cause } \\
\text { and effect } \\
\text { relationship }\end{array}$ & 5 & 3 & 2 & Loss & & 4 & 2 & Loss & \\
\hline \multirow{4}{*}{$\begin{array}{l}\text { Reorganizati } \\
\text { on } \\
\text { Comprehens } \\
\text { ion }\end{array}$} & Classify & 5 & 4 & 3 & Loss & & 2 & 2 & $\begin{array}{l}\text { No } \\
\text { effect }\end{array}$ & \\
\hline & Outline & 5 & 2 & 2 & No effect & & 2 & 2 & $\begin{array}{l}\text { No } \\
\text { effect }\end{array}$ & \\
\hline & Summarize & 5 & 1 & 3 & Gain & & 1 & 2 & Gain & \\
\hline & Synthesize & 5 & 2 & 2 & No effect & & 3 & 2 & Loss & \\
\hline \multirow{2}{*}{$\begin{array}{l}\text { Inferential } \\
\text { Comprehens } \\
\text { ion }\end{array}$} & $\begin{array}{l}\text { Make } \\
\text { inference }\end{array}$ & 5 & 3 & 2 & Loss & & 2 & 1 & Loss & \\
\hline & $\begin{array}{l}\text { Draw } \\
\text { conclusion }\end{array}$ & 5 & 3 & 2 & Loss & & 2 & 1 & Loss & \\
\hline
\end{tabular}

$P<0.05$

Ho. There is no significant difference between the impact of summer vacations on retention level in reading comprehension among the learners of urban and rural schools.

H1. There is a significant difference between the impact of summer vacations on retention level in reading comprehension among the learners of urban and rural schools.

The $\mathrm{t}$-values are significant at $\mathrm{p}<0.05$ level of significance. Therefore, it can be concluded that the null hypothesis (1-Ho) is rejected. Thus, it can be said that summer vacations put the impact of students' performance in reading comprehension. In order to present a clear picture of the obtained scores of urban and rural schools, a bar graph is drawn in Figure 3. 


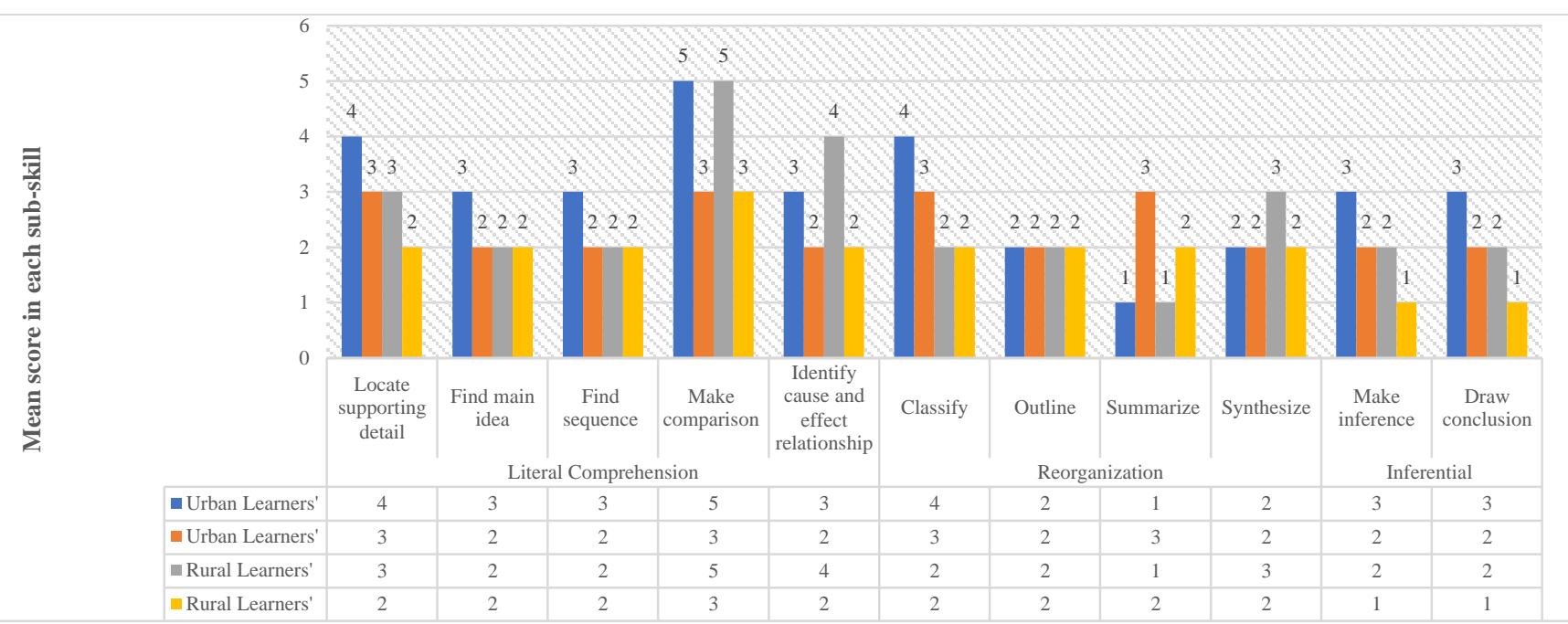

Figure 3 Urban and rural learners' scores in pre-test and post-test

Following two hypotheses were made in order to answer RQ 3: What is difference between the impact of summer vacations among private and public school learners' retention in reading comprehension?

Ho. There is no significant difference between the impact of summer vacations on retention level in reading comprehension among the learners of private and public schools.

H1. There is a significant difference between the impact of summer vacations on retention level in reading comprehension among the learners of private and public schools. In the light of these hypotheses, the results are analyzed and presented in Table 3.

Table 3 Mean scores of private and public schools' learners in reading comprehension

\begin{tabular}{|c|c|c|c|c|c|c|c|c|c|c|}
\hline \multirow[b]{2}{*}{$\begin{array}{l}\text { Major reading } \\
\text { skill }\end{array}$} & \multirow[b]{2}{*}{ Sub-skill } & \multirow[b]{2}{*}{$\begin{array}{l}\text { Score in } \\
\text { each skill }\end{array}$} & \multicolumn{4}{|c|}{ Learners of Private Schools $(n=120)$} & \multicolumn{4}{|c|}{ Learners of Public Schools $(n=120)$} \\
\hline & & & $\begin{array}{l}\text { Pre- } \\
\text { test } \\
\text { Score }\end{array}$ & $\begin{array}{l}\text { Post- } \\
\text { test } \\
\text { Score }\end{array}$ & Finding & $+\frac{0}{3}$ & $\begin{array}{l}\text { Pre- } \\
\text { test } \\
\text { Score }\end{array}$ & $\begin{array}{l}\text { Post-test } \\
\text { Score }\end{array}$ & Finding & $+\frac{0}{\frac{7}{7}}$ \\
\hline \multirow{5}{*}{$\begin{array}{l}\text { Literal } \\
\text { Comprehension }\end{array}$} & $\begin{array}{l}\text { Locate } \\
\text { supporting } \\
\text { detail }\end{array}$ & 5 & 4 & 4 & No effect & \multirow{11}{*}{0.03} & 4 & 4 & No effect & \multirow{11}{*}{0.02} \\
\hline & $\begin{array}{l}\text { Find main } \\
\text { idea }\end{array}$ & 5 & 5 & 3 & Loss & & 4 & 3 & Loss & \\
\hline & $\begin{array}{l}\text { Find } \\
\text { sequence }\end{array}$ & 5 & 4 & 3 & Loss & & 3 & 4 & Loss & \\
\hline & $\begin{array}{l}\text { Make } \\
\text { comparison }\end{array}$ & 5 & 5 & 4 & Loss & & 5 & 4 & Loss & \\
\hline & $\begin{array}{l}\text { Identify } \\
\text { cause and } \\
\text { effect } \\
\text { relationship }\end{array}$ & 5 & 5 & 5 & No effect & & 3 & 4 & Gain & \\
\hline \multirow{4}{*}{$\begin{array}{l}\text { Reorganization } \\
\text { Comprehension }\end{array}$} & Classify & 5 & 4 & 3 & Loss & & 3 & 3 & No effect & \\
\hline & Outline & 5 & 4 & 3 & Loss & & 4 & 2 & Loss & \\
\hline & Summarize & 5 & 3 & 3 & No effect & & 4 & 3 & Loss & \\
\hline & Synthesize & 5 & 4 & 3 & Loss & & 4 & 2 & Loss & \\
\hline \multirow{2}{*}{$\begin{array}{l}\text { Inferential } \\
\text { Comprehension }\end{array}$} & $\begin{array}{l}\text { Make } \\
\text { inference }\end{array}$ & 5 & 3 & 4 & Gain & & 3 & 1 & Loss & \\
\hline & $\begin{array}{l}\text { Draw } \\
\text { conclusion }\end{array}$ & 5 & 3 & 3 & No effect & & 4 & 1 & Loss & \\
\hline
\end{tabular}

$P<0.05$ 
Table 3 indicates the mean scores of private and public school learners in pre-test and post-test as well. It shows that the learners of private schools obtained maximum scores (5 out of 5 ) in two subskills of literal comprehension, namely; finding the main idea and making comparison with pre-test while they got the maximum score ( 5 out of 5 ) in one sub-skill of literal comprehension e.g. identifying cause and effect relationship between post-test. As regards the performance of learners of public schools, they obtained a maximum score (5 out of 5 ) in one sub-skill of literal comprehension such as making comparison with pre-test while they could not get maximum score in any of the sub-skills in post-test. In addition, the performance of the learners in public schools was very poor in two sub-skills of inferential comprehension, namely; making inference and drawing conclusion since they got score 1 in each sub-skill. It reveals that the learners lose their performance in reading comprehension after summer vacations. The calculated t-values (0.03 and 0.02 ) indicates that there is a significant difference between the mean scores of private and public school learners in pre-test and post-test as well. The $\mathrm{t}$-values are significant at $\mathrm{p}<0.05$ level of significance. Therefore, it can be concluded that the null hypothesis (3-Ho) is rejected. Thus, it can be said that summer vacations put a negative impact on students' performance in reading comprehension. In order to present a clear picture of the obtained scores of private and public school learners in pre-test and post-test, a bar graph is drawn in Figure 4.

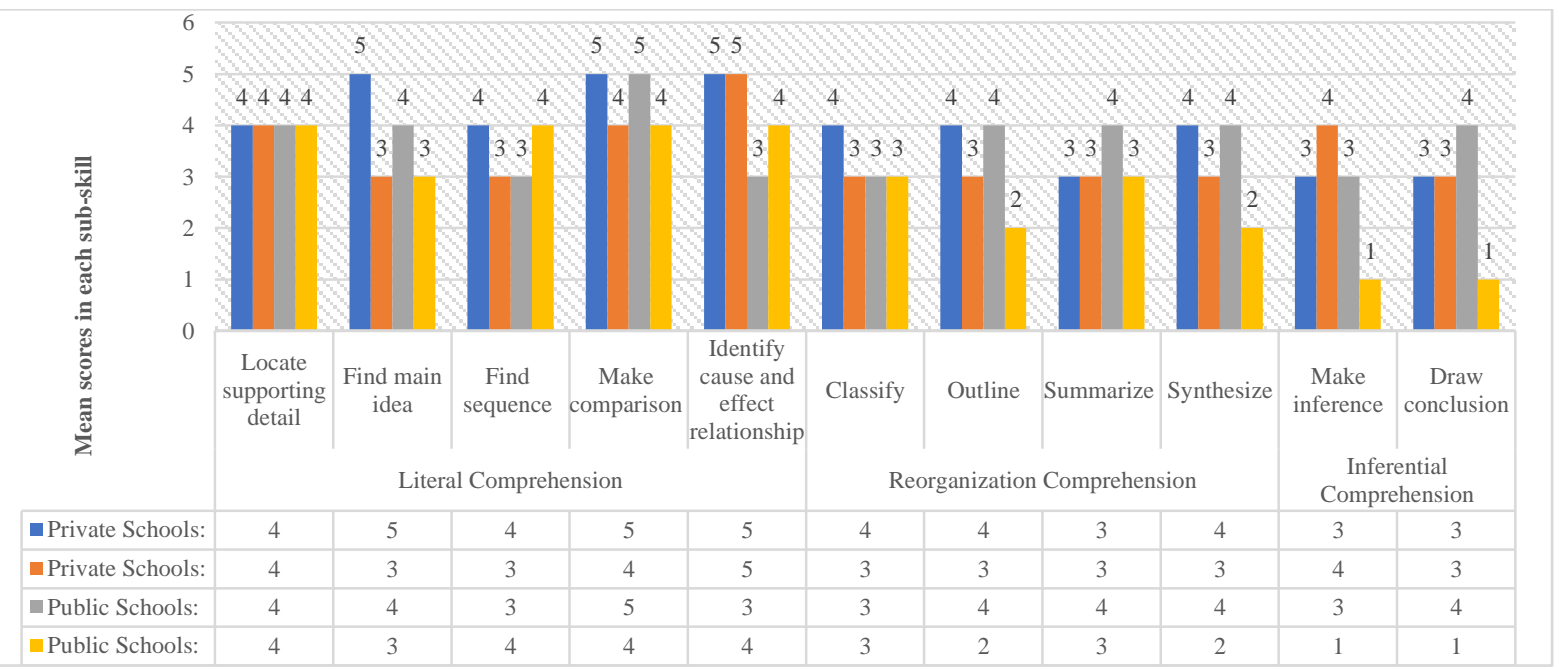

Figure 4 Performance of private and public schools' learners in pre-test and post-test

Following two hypotheses were made in order to answer RQ 4: What is difference between the impact of summer vacations among male and female learners' retention in reading comprehension?

$\mathbf{H}_{\mathbf{o}}$. There is no significant difference between the impact of summer vacations on retention level in reading comprehension among males and females.

$\mathbf{H}_{\mathbf{1}}$. There is a significant difference between the impact of summer vacations on retention level in reading comprehension among males and females.

In the light of these hypotheses, the results are analyzed and presented in Table 4. 
Table 4 Mean Scores of male and female learners in reading comprehension

\begin{tabular}{|c|c|c|c|c|c|c|c|c|c|c|}
\hline \multirow[b]{2}{*}{$\begin{array}{l}\text { Major } \\
\text { reading } \\
\text { skill }\end{array}$} & \multirow[b]{2}{*}{ Sub-skill } & \multirow{2}{*}{$\begin{array}{l}\text { Score } \\
\text { in } \\
\text { each } \\
\text { skill }\end{array}$} & \multicolumn{4}{|c|}{ Males $(n=120)$} & \multicolumn{4}{|c|}{ Females $(n=120)$} \\
\hline & & & $\begin{array}{l}\text { Pre- } \\
\text { test } \\
\text { Score }\end{array}$ & $\begin{array}{l}\text { Post-test } \\
\text { Score }\end{array}$ & Finding & $+\frac{0}{\frac{0}{7}}$ & $\begin{array}{l}\text { Pre-test } \\
\text { Score }\end{array}$ & $\begin{array}{l}\text { Post-test } \\
\text { Score }\end{array}$ & Finding & $\begin{array}{r}\stackrel{0}{7} \\
+\frac{\pi}{>} \\
\end{array}$ \\
\hline \multirow{5}{*}{$\begin{array}{l}\text { Literal } \\
\text { Comprehen } \\
\text { sion }\end{array}$} & $\begin{array}{l}\text { Locate supporting } \\
\text { detail }\end{array}$ & 5 & 3 & 3 & No effect & \multirow{11}{*}{0.01} & 4 & 3 & Loss & \multirow{11}{*}{0.00} \\
\hline & Find main idea & 5 & 4 & 2 & Loss & & 4 & 4 & No effect & \\
\hline & Find sequence & 5 & 3 & 3 & No effect & & 4 & 3 & Loss & \\
\hline & Make comparison & 5 & 4 & 4 & No effect & & 5 & 3 & Loss & \\
\hline & $\begin{array}{l}\text { Identify cause and } \\
\text { effect relationship }\end{array}$ & 5 & 4 & 4 & No effect & & 4 & 4 & No effect & \\
\hline \multirow{4}{*}{$\begin{array}{l}\text { Reorganizat } \\
\text { ion } \\
\text { Comprehen } \\
\text { sion }\end{array}$} & Classify & 5 & 4 & 2 & Loss & & 3 & 3 & No effect & \\
\hline & Outline & 5 & 3 & 2 & Loss & & 4 & 3 & Loss & \\
\hline & Summarize & 5 & 3 & 2 & Loss & & 3 & 3 & No effect & \\
\hline & Synthesize & 5 & 3 & 3 & No effect & & 4 & 2 & Loss & \\
\hline \multirow{2}{*}{$\begin{array}{l}\text { Inferential } \\
\text { Comprehen } \\
\text { sion }\end{array}$} & Make inference & 5 & 3 & 2 & Loss & & 3 & 2 & Loss & \\
\hline & Draw conclusion & 5 & 3 & 2 & No effect & & 4 & 2 & Loss & \\
\hline
\end{tabular}

$P<0.05$

Table 4 indicates the mean scores of males and females in each sub-skill in pre-test and post-test as well. It shows that neither males nor females got score 5 out of 5 in any of reading sub-skills in pretest or post-test.

The calculated t-values (o.oo and 0.00 ) indicate that there a significant difference between the mean scores of males and females in pre-test and post-test as well. The t-values are significant at $\mathrm{p}<0.05$ level of significance. Therefore, it can be concluded that the null hypothesis (5-Ho) is rejected. Thus, it can be said that summer vacations put a negative impact on the performance of males and females in reading comprehension. In order to present a clear picture of the obtained scores of males and females in pre-test and post-test, a bar graph is drawn in Figure 5.

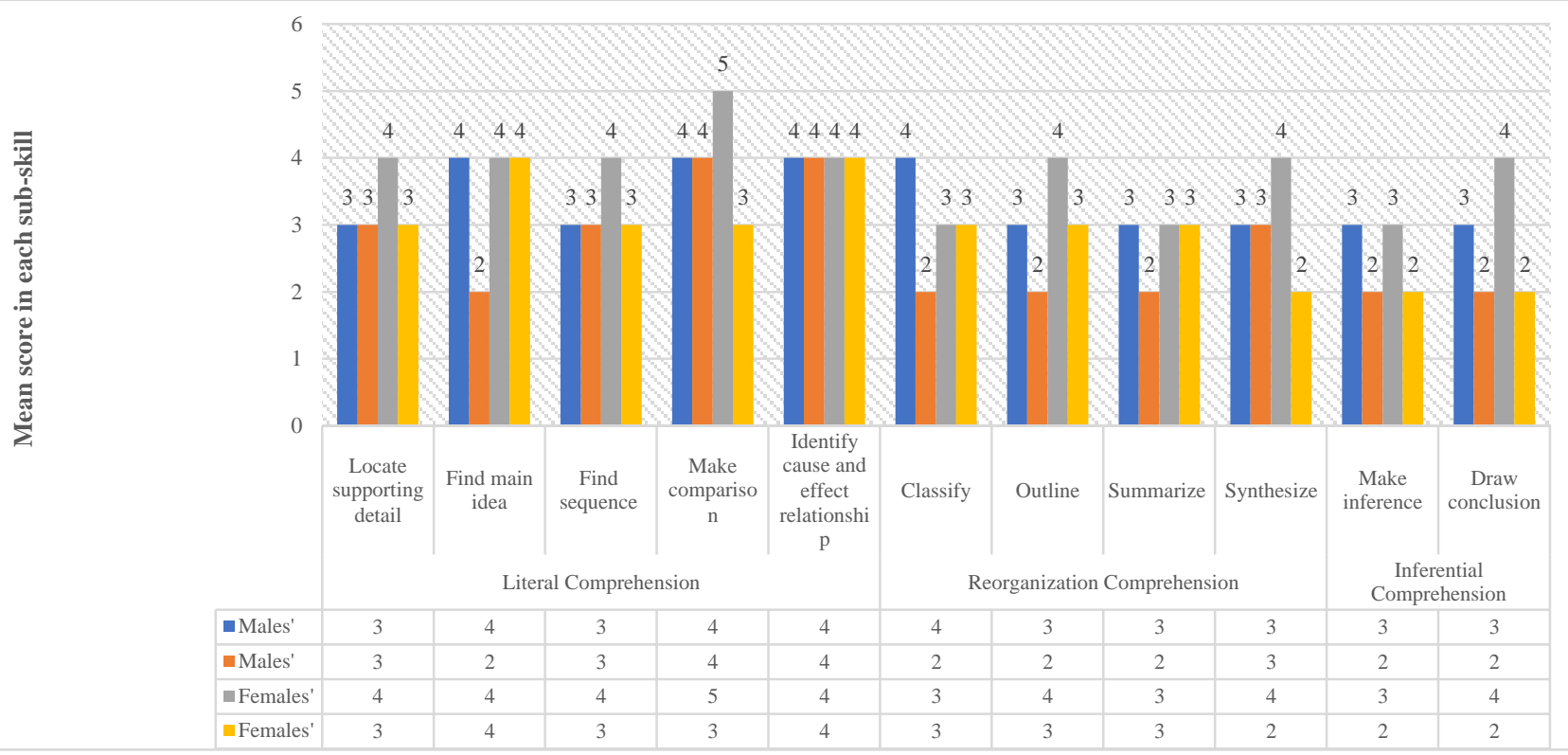

Figure 5 Performance of male and female learners in pre-test and post-test 


\section{Discussion and Conclusion}

The results of the current study indicate that the learners obtained less scores in post-test as compared to their scores got in pre-test. Particularly, the learners diminish their performance in three sub-skills of literal comprehension such as locating supporting details, finding main ideas, identify cause and effect relationship, three sub-skills of reorganization comprehension such as classifying, outlining, synthesizing, and both the sub-skills under inferential comprehension, namely; making inferences and drawing conclusion. It can be concluded that the decline in the performance of these sub-skills is due to summer vacations. The learners did not continue their academic activities and lose their performance. These findings are consistent with findings of Cooper, Nye, Charlton, Lindsay, and Greathouse (1996). They integrated 39 research studies and included in their meta-analysis. The combined research reveals that the learners decline their performance in reading comprehension after summer vacations. Based on the meta-analysis, a significant difference in the effect of summer vacation on different reading skills was found. The findings of the study are also in line with the findings of a study conducted by Kim (2004) Phillips and Chin (2004) who concluded that the learners lose their performance because of summer vacations. The current study reveals that summer vacations put no effects of two sub-skills of literal comprehension such as finding sequence and making comparison and one sub-skills of reorganization comprehension, namely summarizing. These findings are consistent with the results of a study carried out by Alexander, Entwisle, and Olson (2007) who found no significant loss in reading comprehension as compared to other areas.

The current study also reveals that the male and female learners of urban and rural schools and private and public schools also lose their performance in reading comprehension after summer vacations. At the end of the summer vacations, there was no evidence that the learners made significant reading gains. In addition, the calculated t-values for the learners of urban and rural schools, private and public schools and males and females indicate that there was a significant difference in loss of reading comprehension based on geographical locations, public and private schools and gender. These findings are consistent with the findings of past studies by Kim and White (2008), which concluded that the learners declined their performance in reading comprehension due to summer vacations. Cooper et al. (1996) found a dramatic difference in performance of students in different skills, however, the loss was more severe in other subject as compared to reading comprehension because of summer vacations. Allinder and Eicher (1994) carried out a study and concluded in their study that learners' performance declined significantly in reading comprehension. However, interestingly, this is contrary to a study conducted by Helf, Konrad, and Algozzine (2008) who found that students did not regress over the summer; in fact, they improved their performances in different skills of reading comprehension.

In a nutshell, based on the findings of the study, the researcher can speculate that the learners' home environment does not provide more opportunities to engage themselves in different academic activities. Parents might not be well educated or well-aware of the importance of reading, so they don't pay attention to keeping their children reading over summer vacations. The main findings of the current study corroborate reading loss in summer vacations, which suggest school administrators, ESL teachers, learners and parents as well for increasing summer reading activities.

\section{References}

Airasian, P., Gay, L., \& Mills, G. (2000). Educational research: Competencies for analysis and application. New Jersey, Upper Saddle: Prentice Hall.

Alderson, J. C., \& Urquhart, A. H. (1984). Reading in a foreign language. London: Longman. 
Alexander, K. L., Entwisle, D. R., \& Olson, L. S. (2007). Summer learning and its implications: Insights from the Beginning School Study. New Directions for Youth Development, 2007(114), 11-32.

Allinder, R.M. \& Eicher, D.D. (1994). Bouncing back: Regression and recoupment among students with mild disabilities following summer break. Special Services in the Schools, 8, 129-142.

Anderson, N. J. (2003). Scrolling, clicking, and reading English: Online reading strategies in a second/foreign language. The Reading Matrix, 3(3), 1-33.

Barrett, T. C. (1968). What is reading? Some current concepts. In H. M. Robinson (Ed.) Innovation and change in reading instruction: The sixteenth handbook of the National

Society for the Study of Education. Chicago: The University of Chicago Press.

Block, C. C., \& Parris, S. R. (2008). Comprehension instruction: Research-based best practices: New York, NY: The Guilford Press.

Bonito, J. A., Ruppel, E. K., \&Keyton, J. (2012). Reliability Estimates for Multilevel Designs in Group Research. Small Group Research, 43(4), 443-467.

Catts, H. W., \&Kamhi, A. G. (2005). The connections between language and reading disabilities. New York, NY: Psychology Press.

Cleland, D. L. (1965). A construct of comprehension. Reading and Inquiry, 59-64.

Cooper, H., Nye, B., Charlton, K., Lindsay, J., \& Greathouse, S. (1996). The effects of summer vacation on achievement test scores: A narrative and meta-analytic review. Review of Educational Research, 66(3), 227-268.

García, G. E. (1991). Factors influencing the English reading test performance of Spanish- speaking Hispanic children. Reading Research Quarterly, 371-392.

Government of Pakistan (2006). National Curriculum for English Language; Grades 1-XII 2006. Ministry of Education. Islamabad, Pakistan. Retrieved from http://www.ibe.unesco.org/curricula/pakistan/pk__al_eng_20o6_eng.pdf

Graves, M. F., Juel, C., \& Graves, B. B. (1998). Teaching Reading in the 21st Century. Order Processing, Allyn and Bacon, PO Box 11071, Des Moines, IA 50336-1071.

Helf, S., Konrad, M., \& Algozzine, B. (2008). Recouping and rethinking the effects of summer vacation on reading achievement. Journal of Research in Reading, 31(4), 420-428.

Hertzog, M. A. 2008. Considerations in determining sample size for pilot studies. Research in nursing \& health, $31 \quad(2), 180-191$.

Kieffer, M. J., \&Lesaux, N. K. (2008). The role of derivational morphology in the reading comprehension of Spanish-speaking English language learners.Reading and Writing, 21(8), 783-804.

Kim, J. (2004). Summer reading and the ethnic achievement gap. Journal of Education for Students Placed at Risk, 9(2), 169-188.

Kim, J. S., \& White, T. G. (2008). Scaffolding voluntary summer reading for children in grades 3 to 5: An experimental study. Scientific Studies of Reading, 12(1), 1-23.

Oakhill, J., Kate, C., \& Carsten, E. (2015). Understanding and Teaching Reading Comprehension A Handbook. London \& New York: Routledge.

Pagan, S., \&Sénéchal, M. (2014). Involving Parents in a Summer Book Reading Program to Promote Reading Comprehension, Fluency, and Vocabulary in Grade 3 and Grade 5 Children. Canadian Journal of Education, 37(2), 1.

Pakistan Meteorological Department. (2015). Climate processing centre. Derived from http://www.pmd.gov.pk/cdpc/home.htm

Peregoy, S. F., \& Boyle, O. F. (2005). Reading, writing, and learning in ESL A resource book for K-12 teachers. New York, NY Pearson Education

Phillips, M., \& Chin, T. (2004). How families, children, and teachers contribute to summer learning and loss. In G. Borman \& M. Boulay (Eds.), Summer learning: Research, policies, and programs. 
Mahwah, NJ: Lawrence Erlbaum Associates, Inc.

Pikulski, J. J., \& Chard, D. J. (2005). Fluency: Bridge between decoding and reading comprehension. The Reading Teacher, 58(6), 510-519.

Richards, J. C. \& Schmidt, J. (2010). Longman dictionary of language teaching and applied linguistics (4th Ed). Harlow: Pearson.

Samuels, S. J. (2012). Reading fluency.Fluency Instruction: Research-Based Best Practices. New York, NY: The Guilford Publications, Inc.

Siddique, H. (2011).Students plan various activities during summer vacations. Derived from http://www.pakistantoday.com.pk/2011/05/29/city/lahore/students-plan-variousactivities-during-summer-vacations/

Snow, C. (2002). Reading for understanding: Toward an R\&D program in reading comprehension. Rand Corporation.

Stanovitch, K. E. (1991). Word recognition: Changing perspectives. In R. Barr, M. Kamil, P. Mosenthal, \& P. D. Pearson (Eds.), Handbook of reading research: Volume II (pp. 418452). New York: Longman.

Vellutino, F. R., \& Scanlon, D. M. (2001). Emergent literacy skills, early instruction, and individual differences as determinants of difficulties in learning to read: The case for early intervention. In S. B. Neuman\& D. K. Dickinson (Eds.), Handbook of early literacy research (pp. 295-321). New York: The Guilford Press.

Vellutino, F. R, Scanlon, D. M., \& Lyon, G. R. (2000). Differentiating between difficult to remediate and readily remediated poor readers: More evidence against the IQ Achievement discrepancy definition of reading disability. Journal of Learning Disabilities, 33(3), 223-238.

Yaping, C. (2002). The application of schema theory in second language reading. Foreign Language Education, 5, 10-21. 